\title{
Problemli İnternet Kullanımında Güncel Bir Risk Faktörü: COVID-19 Pandemisi
}

\author{
A Current Risk Factor in Problematic Internet Use: The COVID-19 Pandemic
}

\section{Önder BALTACI[1] Ömer Faruk AKBULUT ${ }^{[2]}$ Ebru YILMAZ ${ }^{[3]}$}

Bu araştırmada, problemli internet kullanımı açısından güncel bir risk faktörü olarak ele alınabilecek COVID-19 pandemisi alanyazın ışığında incelenmiştir. Araştırmada ilk olarak COVID-19 pandemisinin oluşturduğu psiko-sosyal etkiler çeşitli ülkelerde yapılan araștırmalar ışığında ele alınmıştır. Yapılan bu araştırmalarda, COVID-19 pandemisinin fiziksel yansımalarının yanı sıra psikolojik ve sosyal yansımalarının da önemli olduğunu göstermektedir. Araştırmalarda, bireylerin bu dönemde yoğun bir şekilde depresyon, kaygı ve stres gibi psikolojik belirtiler gösterdikleri görülmüștür. Araștırmada daha sonra problemli internet kullanımını açıklayan kuramlar ve modeller ışığında COVID-19 pandemisi döneminde problemli internet kullanım riski açıklanmıştır. Bu dönemde yaşanan problemli internet kullanımı riski bir model ile açılanmıştır. Modelde, COVID-19 pandemisinin sosyal izolasyonu beraberinde getirdiği ve sosyal izolasyonla birlikte bireylerin psiko-sosyal sorunlar yaşadıkları ve internette geçirdikleri sürenin arttığı söylenebilir. Yaşanan bu psiko-sosyal sorunlar ile internette geçirilen sürenin artması birbirlerini etkilemekle birlikte problemli internet kullanımı riskinin olușmasına da yol açabileceği söylenebilir. Araștırmada daha sonra, COVID-19 pandemisi döneminde problemli internet kullanımı riskiyle ilişkili yapılan araştırmalar incelenmiştir. Alanyazındaki araştırmalarda, COVID-19 pandemisiyle birlikte bireylerin problemli internet kullanım oranlarında önemli artışlar göründügü ve bu durumun bireylerin psikososyal sağlıkları açısından olumsuz etkiler olușturduğu görülmüștür. Son olarak ise COVID-19 döneminde çocukların, ergenlerin ve yetişkinlerin problemli internet kullanımı riskinden korunabilmelerine yönelik kurum ve kuruluşlara, ruh sağlığı uzmanlarına, bireylere ve ebeveynlere çeşitli önerilerde bulunulmuştur.

Anahtar Kelimeler: problemli internet kullanımı, internet bağımlılığı, COVID-19, pandemi, risk faktörü

In this study, the COVID-19 pandemic, which can be considered as a current risk factor in terms of problematic internet use, was examined in the light of the literature. In the research, firstly, the psycho-social effects caused by the COVID-19 pandemic were discussed in the light of researches conducted in various countries. These studies show that the psychological and social repercussions of the COVID-19 pandemic are important as well as the physical implications. Studies have shown that individuals intensely show psychological symptoms such as depression, anxiety and stress during this period. Later in the research, the risk of problematic internet use during the COVID-19 pandemic was explained in the light of theories and models explaining problematic internet use. Problematic internet use risk experienced in this period was explained with a model. In the model, it can be said that the COVID-19 pandemic brought along social isolation, and with social isolation, individuals experience psycho-social problems and the time they spend on the internet increases. It can be said that these psycho-social problems and the increase in the time spent on the internet affect each other, but may also lead to the risk of problematic internet use. Subsequently, the research examined the studies related to the risk of problematic internet use during the COVID-19 pandemic. In the researches in the literature, it has been observed that with the COVID-19 pandemic, there has been a significant increase in the problem of internet use of individuals and this situation has negative effects on the psycho-social health of individuals. Finally, in the period of COVID-19, various recommendations have been made to institutions and organizations, mental health professionals, individuals and parents to protect children, adolescents and adults from the risk of problematic internet use.

Keywords: problematic internet use, internet addiction, COVID-19, pandemic, risk factor

[1] Dr. Öğr. Üyesi | Kırşehir Ahi Evran Üniversitesi | Eğitim Fakültesi | Kırşehir | Türkiye | ORCID: 0000-0002-9974-8507

[2] Yüksek Lisans Öğrencisi | Necmettin Erbakan Üniversitesi | Konya | Türkiye | ORCID: 0000-0001-5152-8102 | omerfaruk2540@gmail.com

[3] Psikolojik Danıșman | MEB | Türkiye | ORCID: 0000-0001-5134-9139 


\section{GíRiş}

Ç in'de 2019 yılı sonlarına doğru başlayan ve bütün Dünya'ya hızlı bir şekilde yayılan SAR-CoV-2'den kaynaklanan COVID-19 hastalığı 2020 yılı içerisinde büyük bir yayılım göstererek küresel bir sorun haline gelmiş ve Dünya Sağlık Örgütü (WHO) tarafından pandemi olarak nitelendirilmiştir (T.C. Sağlık Bakanlı̆̆ı, 2020; WHO, 2020). COVID-19 pandemisinin hızlı bir şekilde yayılım göstermesi ve ölümcül etkilere sahip olması birçok ülkenin eğitim, mesleki ve sosyal yaşam alanlarında farklı kısıtlamalar uygulamalarına neden olmuştur. Ülkemizde bu kapsamda; çeşitli yaş gruplarına yönelik sınırlı saatler haricinde sokağa çıkma kısıtlaması getirilmesi, okul öncesinden yükseköğretime kadar eğitim kademelerinin faaliyetlerini uzaktan eğitim yoluyla devam ettirmeleri, hafta sonları sokağa çıkma kısıtlamalarının getirilmesi ve seyahat kısıtlamaları gibi farklı önlemlerin alındığı bilinmektedir (BBC Türkçe, 2020; T.C. Sağlık Bakanlı̆̆ı, 2020). Bunlara ek olarak bireylerin bu hastalığa yakalanmamak için kendilerini izole ettikleri ve sosyal yaşamdaki etkileşimlerinde azalmalar olduğu bilinmektedir (Ruiz-Frutos vd., 2020). Ayrıca bireylerin bu dönemde medya araçlarında sürekli olarak COVID-19 pandemisiyle ilgili haberlere maruz kalmaları da yoğun stres ve kaygı yașamalarına neden olduğu görülmüștür (Al Zubayer vd, 2020; Gao vd., 2020; Planchuelo-Gómez vd., 2020; Wang vd., 2020).

Bireylerin COVID-19 pandemisi öncesine göre sosyal yaşamlarındaki etkileşimlerinde görülen bu azalmalar ve evde geçirilen sürenin artması fiziksel sağlık açısından koruyucu bir role sahip olsa da psikososyal sağlık açısından çeşitli sorunların yaşanması açısından risk oluşturabilmektedir (Benke vd., 2020). Statista (2021) tarafından Amerika Birleşik Devletleri'nde COVID-19 pandemisi sürecinde internet kullanım oranları üzerine yapılan bir araştırmada, bireylerin pandemi öncesine göre internet kullanım oranlarının arttığı görülmüştür. Ayrıca yapılan başka bir araştırmada COVID-19 pandemisi döneminde çocukların ekran başında geçirdikleri sürenin de büyük oranda artış gösterdiği görülmüştür (Griffith, 2020). Bireylerin pandemi döneminde çevrimiçi oyunlarda geçirdiği süre de pandemi öncesine göre büyük oranda artış göstermiştir (King vd., 2020). COVID-19 pandemisiyle artan çevrimiçi süre internetin kontrolsüz, bilinçsiz ve aşırı bir şekilde kullanılmasına yol açabilmektedir. İnternetin bu şekilde sorunlu bir şekilde kullanılması alanyazında problemli internet kullanımı, internet bağımlılığı ve patolojik internet kullanımı gibi farklı isimlerle tanımlanmaktadır (Block, 2008; Caplan, 2010; Young ve De Abreu, 2011). Bu araştırmada bu kavramlar arasından problemli internet kullanımı kavramı, internetin sorunlu bir şekilde kullanılması olarak ele alınmıştır. Bu bağlamda araştırmada, bireylerin evde kalmalarıyla birlikte internette geçirdikleri sürelerin artmasıyla beraber psikososyal yaşamları açısından bir sorun olarak algılanabilecek problemli internet kullanımı durumu ele alınacaktır.

Problemli internet kullanımı; bireylerin internet kullanımlarını kontrol etmekte zorluk yaşamaları, internetle ilgili yoğun bilişsel meşguliyet yaşamaları, internete ulaşamadıklarında öfke, huzursuzluk, sinirlilik gibi çeşitli tepkiler yaşamaları ve internet kullanımlarının mesleki, akademik, fiziksel, psikolojik ve sosyal yaşamlarını olumsuz olarak etkilemesi durumu olarak tanımlanmaktadır (Caplan, 2010; Young ve De Abreu, 
2011). Bireylerin internette geçirdikleri sürenin fazla olması, internet kullanımlarını kontrol etmede zorluk yaşamaları ve sağlıklı internet kullanımına ilişkin gerekli becerilere sahip olamamaları problemli internet kullanımına yol açabilmektedir (Avşaroğlu ve Akbulut, 2020). Bu durum sonucunda bireylerin fiziksel, psikolojik ve sosyal yaşamları olumsuz olarak etkilenebilmektedir. Yapılan araştırmalarda; problemli internet kullanımının obezite (Budak, 2016; Yıldırım, 2016), yeme bağımlılı̆̆ı (Tao ve Liu, 2009; Yıldırım, 2016), beslenme sorunları (Dürmüş, 2018), fiziksel aktivitelerde azalma (Mota vd., 2006), akademik başarısızlık (Buzkıran, 2017; Xin vd., 2018), akademik erteleme (Geng et al., 2018), olumsuz okul yaşantıları (Li vd., 2019; Peng vd., 2019), olumsuz ruh sağlığı belirtileri (Budak vd., 2015; Lin vd., 2019; Özcan vd., 2020) ve sağlıssız aile ilişkileri (Chi vd., 2020; Çırak vd., 2018; Wąsiński ve Tomczyk, 2015) gibi fiziksel, psikolojik ve sosyal sorunlar oluşturduğu görülmektedir.

COVID-19 pandemisiyle birlikte bireylerin sosyal yaşamlarındaki etkileşimlerinde görülen azalmalar ve daha fazla evde kalmayla birlikte internette geçirilen sürenin artması problemli internet kullanımı açısından risk oluşturabilmektedir (Balcı vd., 2021; Bayrak Ayas, 2020; Göker ve Turan, 2020; Güleryüz vd., 2020). Bireylerin COVID-19 sürecinde yaşadıkları yoğun kaygı ve stres psiko-sosyal sağlıkları açısından sorunlar oluşturmakla birlikte problemli internet kullanımı sonucunda oluşabilecek psiko-sosyal etkiler de bireylerin ruh sağlığı durumları açısından uzun vadeli olumsuz etkiler yaratabileceği düşünülmektedir.

Tüm bunlar değerlendirildiğinde, problemli internet kullanımı açısından güncel bir risk faktörü olarak ele alınabilecek COVID-19 pandemisinin alanyazın ışığında ele alınması ve bu riskin önlenebilmesine yönelik çeşitli önerilerde bulunulması sahada çalışan ruh sağlığı çalışanlarına ve araştırmacılara yönelik destek sunabileceği düşünülmektedir. Bu kapsamda araştırmada, ilk olarak COVID-19 pandemisinin psiko-sosyal etkileri ele alınacak daha sonra ise problemli internet kullanımını açıklamak için geliştirilen kuram ve modeller COVID-19 pandemisi açısından incelenecektir. Daha sonrasında ise alanyazında pandemi döneminde problemli internet kullanımını inceleyen araştırmalar gözden geçirilerek bu durumu önlemeye yönelik çeşitli önerilerde bulunulacaktır.

\section{COVID-19 Pandemisinin Psiko-Sosyal Etkileri}

COVID-19 pandemisi ortaya çıktıktan sonra ilk olarak bireylerin fiziksel sağlıklarına odaklanılmış ve bireylerin fiziksel sağlıklarını korumaya yönelik çeşitli önlemler alınmıştır. Bu düzenlemeler çerçevesinde bireylerin psiko-sosyal sağlıklarını korumaya yönelik düzenlemeler ihmal edilmiştir. Alanyazında yapılan araştırmalarda, COVID-19 pandemisinin çocuklardan yaşlılara kadar bütün bireylerde önemli psiko-sosyal sorunlar oluşturduğu görülmüștür (Bulut ve Suluk, 2020; Malesza ve Kaczmarek, 2020).

Al Zubayer ve arkadaşları (2020) tarafından Bangladeş’te ilk COVID-19 vakası çıtıktan 4 ay sonra 1.146 yetişkin üzerinde yapılan bir araştırmada; bireylerde depresyon, kaygı ve stresin yaygınlığı cinsiyetler arasında anlamlı farklılık göstermemekle birlikte sırasıyla \%47.2, \%46.0 ve \%32.5 olarak bulunmuştur. Planchuelo-Gómez ve arkadaşları (2020) tarafından İspanya'da COVID-19’un psikolojik yansımalarını 
incelemek için 4.724 katılımcı ile yürütülen bir boylamsal araştırmada ise bireylerin kaygı, depresyon ve stres düzeyleri 1 ay arayla yapılan 2 ölçümde artış gösterdiği görülmüştür. El Keshky ve arkadaşları (2020) tarafından Suudi Arabistan'da karantinaya alınan 200 birey ile yapılan araștırmada, yetişkinlerin karantina sürecinde kaygı, depresyon ve stres belirtilerinin yaygınlığı sırasıyla \%40.5, \%57.5 ve \%55.5 olarak bulunmuştur. COVID-19 pandemisinin ilk ortaya çıktığı Çin'de 472 üniversite öğrencisi ile yapılan başka bir araştırmada ise üniversite öğrencilerine uygulanan SCL-90 envanterinin sonuçları ile COVID-19 döneminde öğrencilerin psikolojik durumları incelenmiştir. Öğrencilerin \%57'si COVID-19’ yakalanma riskinden yoğun korku yaşadıklarını ifade etmişlerdir. Ayrıca öğrencilerin somatizasyon, obsesif kompulsif bozukluk, kişilerarası duyarlılık, anksiyete, fobik anksiyete, paranoid düşünce ve genel şiddet indeksleri normlarla karşılaştırıldığında anlamlı olarak yüksek olduğu görülmüştür (Jiang, 2020). Daha geniş bir çalışma grubu ile Çin'de 323.489 üniversite öğrencisi ile yapılan bir araştırmada, öğrencilerin \%7.7'sinin COVID-19 pandemisi sırasında depresif belirtiler gösterdiği görülmüştür. Depresif belirtileri olan üniversite öğrencilerinin düzenleyici duygusal öz-yeterliliklerinin ise düşük düzeyde olduğu görülmüştür. Ayrıca bu süreçte COVID-19 ile ilgili haberleri günde 3 saatten fazla takip eden öğrencilerin depresyon belirtileri daha yüksek bulunmuştur. Cinsiyet açısından değerlendirildiğinde ise kadın öğrencilerin erkek öğrencilere göre bu süreçte daha fazla depresyon belirtileri gösterdiği görülmüştür. Sınıf düzeyi açısından ele alındığında ise son sınıfa yaklaştıkça depresyon belirtilerinin arttığı görülmüştür. Bu durum üniversite öğrencilerin mezun olmalarıyla birlikte iş yaşamına başlayacakları ve beraberinde pandeminin getirdiği ekonomik etkilerden olumsuz etkilenebilecekleri kaygısı ile açıklanabilir. Yaşanılan yerleşim yeri değişkenine göre ise büyük şehirlerde yaşayan üniversite öğrencilerinin pandemi sırasında depresyon belirtilerinin daha yüksek olduğu görülmüştür. Ayrıca bu süreçte hiç egzersiz yapmayan üniversite öğrencilerinin de diğer gruplara göre daha yüksek depresyon belirtileri yaşadığı görülmüştür. Uyku ve beslenme alışkanlıklarında yaşanılan düzensizlikler de depresif belirtileri artırmıştır (Chen vd., 2020).

COVID-19 vaka ve ölüm sayılarının en fazla görüldüğü ülkelerden birisi olan ABD’de 10.368 birey ile yapılan bir araştırmada ise korku ve kaygı düzeyleri doğrulanmış vaka sayılarının yüksek olduğu bölgelerde daha yüksek bulunmuştur (Fitzpatrick vd., 2020). ABD ile birlikte COVID-19 pandemisinden önemli oranda etkilenen İngiltere'de 17.452 birey ile COVID-19 pandemi öncesinde ve sonrasındaki psikolojik durumu belirleyebilmek için yapılan boylamsal araştırmada; 2014 yılından 2020'nin Nisan ayına kadar olan ki süreçte bireylerin psikolojik durumlarında olumsuz anlamda bir yükseliş olduğu görülmüştür. Araştırmada, katılımcıların 2018-2019 yılları içerisinde klinik olarak psikolojik sıkıntı yaşama oranı \%18.9 iken bu oran Nisan 2020'de \%27.3'e çıkmıştır. Buna ek olarak katılımcıların genel sağlık anketine verdikleri cevaplar incelendiğinde 2018-2019 yılları içerisinde olumsuz sağlık durumları oranı \%11.5 iken Nisan 2020'de \%12.6'ya yükselmiştir. Bu yükselişin 2014-2018 yılları arasındaki ölçümlerdeki yükselmeden daha fazla olduğu görülmüştür. $\mathrm{Bu}$ artışların hangi gruplarda anlamlı olarak daha fazla olduğunu belirlemek için yapılan analizlerde ise en fazla artışın 18-24 ve 25-34 yaş gruplarında, kadınlarda ve küçük çocuklarla birlikte yaşayan gruplarda olduğu görülmüştür. Ayrıca pandemiden önce çalışan ve pandemiyle birlikte işini kaybeden 
katılımcılarda da bu artışın yüksek olduğu görülmüştür (Pierce vd., 2020). Benke ve arkadaşları (2020) tarafından Almanya'da COVID-19 pandemisinin başlangıç döneminde 4.335 birey ile yapılan bir araştırmada, kısıtlamalar ile birlikte gerçekleşen sosyal etkileşimlerdeki azalmalar ve yaşamsal değişiklikler psikolojik durumlar (depresyon, kaygı, yalnızlık, yaşam doyumu ve psikolojik sıkıntılar) ile ilişkili olduğu görülmüştür. COVID-19 pandemisi döneminde bireylerin evlerinde daha uzun süre kalmaları aile içi ilişkilerine ilişkin yansımalar ortaya çlkartabilmektedir. Bu dönemde sorunlu aile ilişkilerine sahip olan bireyler pandeminin yarattığı olumsuz psiko-sosyal deneyimlerden daha fazla etkilendikleri görülmüștür.

COVID-19 pandemisi bütün bireyleri etkilemekle birlikte sağlık sektörü içerisinde yer alan ve COVID-19 hastaları ile yakından temasta bulunan sağlık çalışanları üzerinde daha çok psiko-sosyal etkiler oluşturabileceği söylenebilir. İtalya'da sağlık çalıșanları ile yapılan bir araştırmada, sağlık çalışanlarının COVID-19 hastaları ile çok yakın temaslarda bulunmalarının algılanan stres düzeyleri üzerinde önemli etkiler oluşturduğu görülmüştür (Babore vd., 2020). Benzer bir şekilde Tan ve arkadaşları (2020) tarafından Singapur'da 3.075 sağlık çalışanı ile yürütülen bir araştırmada ise 8 saatten fazla mesaiye kalan sağlık çalışanlarının daha fazla tükenmişlik yaşadığı görülmüştür. Bu dönemde sağlık çalışanlarının tükenmişlik düzeyleri ile depresyon, kaygı ve stres düzeyleri arasında güçlü bir ilişki bulunmuştur. Hastanelerde doktor, hemşire ve yardımcı sağlık personeli olarak çalışan bireylerin tükenmişlik düzeyleri destek personeli ve yönetici pozisyonunda çalışan bireylerin tükenmișlik düzeylerinden anlamlı olarak daha yüksek bulunmuștur. Bu sonuç, COVID-19 tanısı almış bireylerle bire bir temasta bulunan sağlık çalışanlarının daha fazla tükenmişlik yaşadığını göstermektedir.

COVID-19 pandemisi döneminde sağlık çalışanları ile yapılan nitel bir araştırmada ise sağlık çalışanlarının pandemi döneminde psiko-sosyal yaşamlarında önemli etkilenmeler olduğu görülmüştür. Ardebili ve arkadaşları (2020) tarafından 97 sağlık çalışanı ile yapılan bu nitel araştırmada, sağlık çalışanlarının pandemi dönemindeki mesleki ve psikolojik deneyimleri derinlemesine araștırılmak istenmiştir. Araștırma sonucunda; sağlık çalışanlarının pandemi döneminde çalışmayla birlikte aşırı iş yükü, belirsizlik, durum üzerinde kontrolü kaybetmek ve koruyucu cihazların yetersizliği ve kullanımının zorluğunu yașama gibi mesleki anlamda zorluklar yaşadıkları görülmüștür. Sağlık çalıșanları, COVID-19 pandemisinden mesleki anlamda etkilenmekle birlikte günlük yaşamlarında önemli değişiklikler yaşadıklarını ifade etmişlerdir. Araştırmaya katılan tüm sağlık çalıșanlarının pandemi ile birlikte günlük yaşamlarında önemli değișikliklerin olduğunu ve \%95'inin bu durumun eskiye dönmesinin çok zor olacağını ifade ettiği görülmüştür. Sağlık çalışanları pandemi ile birlikte sosyal etkileşimlerinde, aile ilişkilerinde ve iş hayatlarında büyük değişikliklerin meydana geldiğini ve bu değişikliklerin kendilerini psikolojik olarak olumsuz etkilediğini ifade etmişlerdir Ayrıca sağlık çalışanları bu dönemde kendilerini karantinaya almışlar ve ailelerinden uzak kalmışlardır. Araştırmada, sağlık çalışanlarının hastalığı ailelerine bulaştırma veya onları kaybetme korkusu yaşadıkları görülmüştür. Ayrıca araştırmaya katılan sağlık çalışanlarının önemli bir kısmı ailelerinden uzakta hastalığa yakalanıp tek başlarına ölmekten korktuklarını ifade ettikleri görülmüştür. Bazı sağlık çalışanları ise ailelerine 
virüs bulaştığında kendilerini suçlu hissetme duygusunu yaşayabileceklerini ifade etmişlerdir. Araştırmada COVID-19 pandemisinde sağlık çalışanlarının psikolojik durumları teması incelendiğinde psikolojik etkilerin 3 aşamada ele alındığı görülmüștür. Bu bağlamda sağlık çalıșanları pandeminin ilk aylarında korku, kaygı ve kontrol kaybı durumları yaşadıkları görülmüştür. İkinci aşama olan pandeminin zirve yaptığı dönemde ise sağlık çalışanlarında kaygı, depresyon, umutsuzluk ve çaresizlik duygularının yaygın olduğu görülmüştür. Üçüncü aşamada ise sağlık çalışanları artık duruma yavaş yavaş uyum sağlamaya başlasa bile psikolojik olarak olumsuz deneyimlerinin hala devam ettiği görülmüștür. Bu aşamada sağlık çalışanlarında; depresyon, posttravmatik stres, tükenmişlik ve stres durumlarının yeniden ortaya çıkışı gibi psikolojik durumların yaşandığı görülmüştür.

COVID-19 pandemisi sağlık çalışanlarını derin bir şekilde etkilemekle birlikte eğitim-öğretim hizmetlerini uzaktan eğitim yoluyla gerçekleştirmeye başlayan öğretmenler üzerinde de bazı yansımalar oluşturmuştur. MacIntyre ve arkadaşları (2020) tarafından 634 öğretmen ile yapılan bir araştırmada, öğretmenlerin uzaktan eğitim sürecinde stresle başa çıkma stratejileri, stres, iyi oluş ve negatif duyguları arasındaki ilişki incelenmiştir. Araştırmada, uzaktan eğitim sürecinde öğretmenlerin önemli düzeyde stres yaşadıkları görülmüștür. Araştırmada yapılan korelasyon analizinde pozitif psikolojik durumlar (mutluluk, iyi oluş, dayanıklılık vb.) ile pozitif başa çımma stratejileri arasında pozitif yönde anlamlı bir ilişki bulunurken kaçınmacı başa çıkma stratejileri ile negatif yönde anlamlı bir ilişki bulunmuştur. Kaçınmacı başa çıkma stratejileri ile olumsuz psikolojik durumlar (stres, kaygı, mutsuzluk vb.) arasında pozitif yönde orta düzeyde anlamlı bir ilişki bulunmuştur.

COVID-19 pandemisi ile birlikte bireylerin psikolojik ve sosyal yaşamları olumsuz etkilendiği birçok araştırmada görülmektedir. Ancak bireylerin pandemi öncesinde sahip oldukları olumsuz ruh sağlığı belirtileri ve tanıları pandemi döneminin psiko-sosyal yansımalarına karşın daha kırılgan bir yapıya sahip olmalarına ve bu durumdan daha fazla etkilenmelerine neden olabilmektedir. Liu ve arkadaşları (2020) tarafından Amerika'da 898 genç yetişkin ile yapılan bir araştırmada, COVID-19 öncesi herhangi bir psikolojik rahatsızlık tanısı almış ancak tedavi olmamış bireylerin COVID-19 ile ilgili endişe ve üzüntü düzeyleri hiç tanı almayanlara göre daha yüksek bulunmuştur. Ayrıca pandemi öncesinde herhangi bir psikolojik rahatsızlık tanısı almış ancak tedavi görmüş bireylerin tanı alıp tedavi görmeyen bireylere göre daha düşük COVID-19 ile ilgili endișe ve üzüntü duydukları görülmüştür. Bu araştırma, pandemi öncesinde psikolojik rahatsızlık tanısı almış bireylerin pandeminin psiko-sosyal etkilerinden daha fazla etkilendiklerini göstermektedir. Guo ve arkadaşları (2020) tarafından 6.169 ergen ile yapılan bir araștırmada ise COVID-19'un yüksek kaygı ve travma sonrası stres durumlarını açıklama durumu ve pandemi öncesinde kötü muamele yaşama deneyimlerinin ergenlerin pandemi sürecinde ruh sağlığı üzerindeki bu etkiyi arttırıp arttırmaması incelenmiştir. Araştırma sonucunda, COVID-19 pandemisi sürecinde travma sonrası stres ve kaygı durumlarını çocukluk dönemindeki olumsuz deneyimlerin önemli oranda açıkladığı görülmüştür. Ayrıca olumsuz çocukluk deneyimlerine sahip ve COVID19 korkusu yüksek olan ergenlerin, travma sonrası stres düzeylerinin yüksek olduğu görülmüştür. Bu sonuçlar, 
pandemi öncesinde olumsuz çocukluk deneyimlerine maruz kalan ergenlerin pandeminin psikolojik etkilerinden daha fazla zarar gördüklerini gösterebilmektedir.

COVID-19 pandemisinde bireylerin psiko-sosyal durumlarına ilişkin Dünya'da yapılan araştırmalar genel olarak incelendiğinde; Dünya'nın birçok ülkesinde farklı meslek ve yaş gruplarındaki bireylerin COVID-19 pandemisinin beraberinde getirdiği psiko-sosyal etkilere maruz kaldıkları söylenebilir. Bu araştırmada, COVID19 pandemisinin beraberinde getirdiği sorunlardan birisi olan problemli internet kullanımı durumu ele alınmıştır. Bir sonraki bölümde COVID-19 pandemisinde problemli internet kullanımının gelişimini hızlandırabilecek risk faktörleri problemli internet kullanımını açıklamak için geliştirilen model ve kuramlar çerçevesinde ele alınacaktır.

\section{COVID-19 Pandemisinde Problemli İnternet Kullanımının Kuramsal Çerçevesi}

Bireylerin interneti yaşamlarında sorun oluşturacak ve kontrolsüz bir şekilde kullanması olarak tanımlanan problemli internet kullanımı son yıllarda teknolojinin gelişmesiyle birlikte sıklıkla yaşanan bir sorun olarak karşımıza çıkmaktadır (Avşaroğlu ve Akbulut, 2020). COVID-19 pandemisiyle birlikte bireylerin evde geçirdikleri sürenin artması ve beraberinde internette daha fazla vakit geçirmeleri problemli internet kullanımı sorunu açısından risk oluşturabilmektedir (Eidi ve Delam, 2020; Guessoum vd., 2020). Ayrıca stresli durumlar ve olaylar problemli internet kullanımı durumuna neden olabilmektedir (Cerniglia vd., 2017). Bu bölümde, COVID-19 pandemisinde problemli internet kullanımı riskini artıracak faktörler çeşitli kuram ve modeller ışığında ele alınacaktır.

Problemli internet kullanımının bileșenlerinin belirlenmesi üzerine çalışma yapan Block (2008), problemli internet kullanımının aşırı kullanım, geri çekilme, tolerans ve olumsuz etkiler olmak üzere 4 boyuttan oluştuğunu ifade etmiştir. COVID-19 pandemisi döneminde bireylerin internette geçirdikleri sürenin artması ve bu süre üzerinde kontrolün kaybedilmesi bu boyutlardan aşırı kullanım boyutuyla ilişkilidir. Ayrıca bu süreçte bireylerin birçok sorumluluklarını yerine getirmek ve zaman geçirmek için interneti kullanmaları beraberinde internette geçirdikleri sürenin artmasına ve tolerans geliştirmelerine neden olabilmektedir. Bunlara ek olarak bireylerin internette geçirdikleri kontrolsüz süre ile birlikte akademik, mesleki ve psikososyal yaşamlarının olumsuz olarak etkilenmesi de problemli internet kullanımı açısından risk oluşturabilmektedir.

Davis (2001) tarafından problemli internet kullanımını açıklamak için geliştirilen bilişsel-davranışçı modelde ise problemli internet kullanımına bireylerin sosyal kaygı, depresyon, stres, yalnızlık, işlevsel olmayan bilişler ve internetle ilgili pekiştireçlerin neden olabileceği belirtilmektedir. Ayrıca bireylerin günlük yaşamlarında yaşadıkları sosyal destek eksikliği ve sosyal izolasyon gibi durumların da problemli internet kullanımı sorununun yaşanmasına neden olduğu görülmüştür. Kandell (1998) tarafından problemli internet kullanımını açıklamak için geliştirilen bir başka modelde ise bireylerin psikolojik ve sosyal sorunlar yaşamalarının internetin problemli bir şekilde kullanabilmesine neden olabileceği ifade edilmiştir. Alanyazında 
COVID-19 pandemisinin bireylerin psikolojik sorunlar yaşamalarına neden olabileceğine ilişkin birçok araștırma mevcuttur. Bireylerin pandemi sürecinde yaşadıkları bu olumsuz ruh sağlığı belirtileri problemli internet kullanımının yaşanmasına yol açabilmektedir. Çünkü bireyler günlük yaşamlarında yaşadıkları olumsuz ruh sağlığı durumlarından bir kaçış olarak interneti görebilmekte ve kendilerini internette bu sorunlardan uzak olarak görebilmektedir (Király vd., 2020). Bu durum ilk başta bir rahatlama olarak görülmesine karşın zaman geçtikçe gerçeklikten kopuşa ve sorunların daha derin yaşanmasına neden olabilmektedir. $\mathrm{Bu}$ dönemde bireylerin pandeminin getirdiği olumsuz psikolojik durumlar karşısında rahatlamak için internete yönelerek sosyal medyada vakit geçirmeleri, film-dizi izlemeleri, oyun oynamaları kontrol sağlanamadığı zaman sorunlara neden olabilmektedir (Göker \& Turan, 2020).

LaRose ve arkadaşları (2003) tarafından geliştirilen sosyal bilişsel modelde ise bireylerin internete ilişkin yetersiz öz-düzenlemelerinin, depresyonun ve alışkanlık gücünün problemli internet kullanımına yol açabileceği görülmektedir. COVID-19 pandemisinde depresyon yaygınlığının artması ve internet kullanımına ilişkin süresinin artması ile alışkanlık gücünün artması bir risk faktörü oluşturabilmektedir. Bir başka modelde ise bireylerin çevrimiçi sosyal etkileşimleri gerçek yaşamdaki etkileşimlere tercih etmesi, yetersiz özdüzenleme becerisi ve duygudurumda yaşanan sorunlar problemli internet kullanımına neden olabildiği görülmektedir (Caplan, 2010). COVID-19 pandemisinde bireylerin hastalığa yakalanmamak için sosyal etkileşimlerini internet üzerinden sürdürmeye daha fazla ağırlık vermesi, internette geçirdikleri sürenin artması ile öz-kontrolün olumsuz etkilenmesi ve duygudurumda yaşanan olumsuz durumlar problemli internet kullanımının gelişimi açısından risk oluşturabileceği söylenebilir.

Tam ve Walter (2013) tarafından problemli internet kullanımını açıklamak için risk ve koruyucu faktörlere vurgu yapan modelde ise sağlıksız aile yapısı, olumsuz ruh sağlı̆̆ belirtileri, sıklıkla teknolojiyle uğraş gibi faktörlerin problemli internet kullanımının gelişimini hızlandırıcı faktörler olduğu ifade edilmiştir. COVID-19 pandemisinde bireylerin aile ilişkilerinde yaşanan sorunların artması, olumsuz ruh sağlığı belirtileri göstermesi ve internette sıklıkla vakit geçirmeleri problemli internet kullanımı açısından risk oluşturabilmektedir. Çünkü bireylerin aile ilişkilerinde yaşadıkları sorunlardan ve olumsuz ruh sağlığı belirtilerinden kaçınmak için interneti kullanmaları sonucunda gerçek yaşamdan kopmalar başlayabilmektedir.

Maslow'un ihtiyaçlar hiyerarşisi temel alınarak problemli internet kullanımını açıklayan Suler (1999), bireylerin gerçek yaşamda karşılamaları gereken temel ihtiyaçları internet üzerinden karşılamaları ve bu durumun sıklıkla yaşanmasının problemli internet kullanımına neden olabileceğini ifade etmiştir. COVID-19 pandemisi döneminde bireylerin fizyolojik, güvenlik, kişilerarası ilişkiler, sosyal kabul, bilme, anlama ve saygı gibi çeşitli ihtiyaçlarını internet üzerinden karşılamaları ve bu durumun yoğun bir şekilde devam etmesi problemli internet kullanımı açısından risk oluşturabileceği söylenebilir.

Son olarak Liu ve Kuo (2007) tarafından geliştirilen kişilerarası ilişkiler modelinde ise bireylerin gerçek yaşamlarındaki kişilerarası ilişkilerinde yaşadıkları sorunlardan bir kaçış olarak internete yönelebileceklerini ve bu durumun problemli internet kullanımı açısından risk oluşturabileceği vurgulanmıştır. COVID-19 
pandemisi döneminde bireylerin gerçek yaşamdaki kişilerarası ilişkilerinde yaşanan azalmalar ve bu ilişkilerin internet üzerinden daha fazla gerçekleştirilmesi problemli internet kullanımı açısından risk oluşturabileceğini göstermektedir.

Problemli internet kullanımını açıklamak için geliştirilen bu kuram ve modeller incelendiğinde, bireylerin COVID-19 pandemisinde karşılaştıkları birçok faktörün problemli internet kullanımının gelişimi açısından risk oluşturabildiğini göstermektedir. Problemli internet kullanımının gelişimini hızlandıracak risk faktörlerinden bir yenisi de COVID-19 pandemisi olduğu söylenebilir. Şekil 1'de bu kuramlar ve modeller ışığında COVID-19 pandemisi döneminde problemli internet kullanımı riskinin gelişimine ilişkin süreç özetlenmiştir.

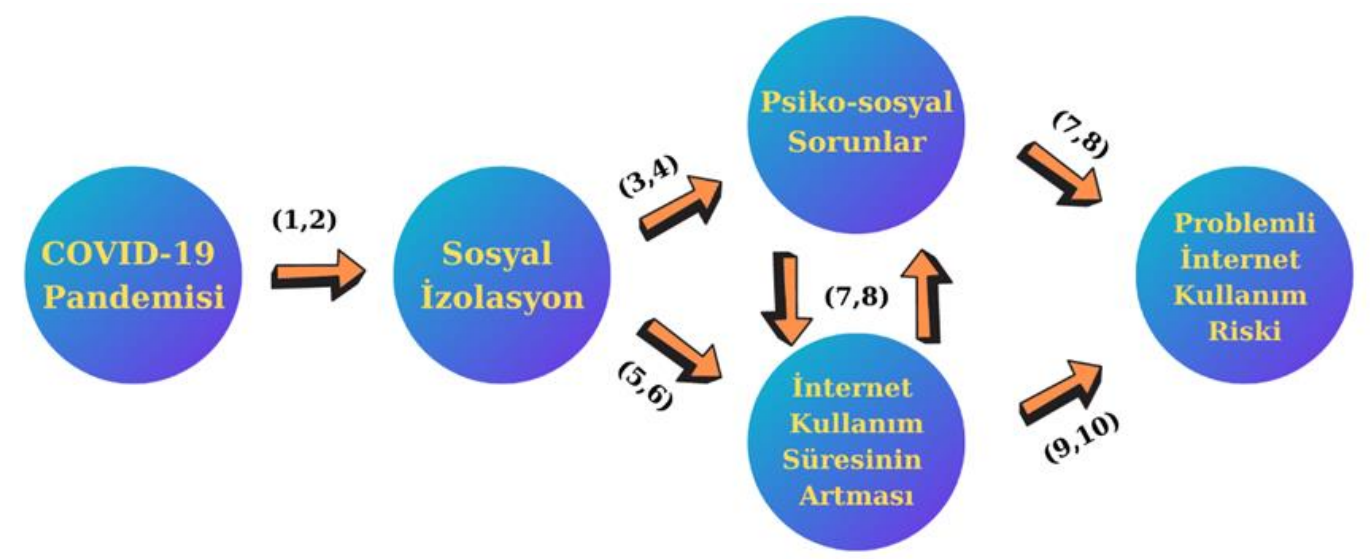

1-) Benke ve arkadaşları, 2020; 2-) Ardebili ve arkadaşları (2020); 3-) Al Zubayer ve arkadaşları (2020); 4-) Jiang (2020); 5-) Özdemir ve Arpacığlu (2020); 6-) Sun ve arkadaşları (2020); 7-) Davis (2001); 8-) Kandell (1998); 9-) Siste ve arkadaşlari (2020); 10-) Young ve De Abreu (2011)

Şekil 1. COVID-19 Pandemisi Döneminde Problemli İnternet Kullanım Riski

Şekil 1 incelendiğinde; COVID-19 pandemisinin beraberinde sosyal izolasyon durumunu ortaya çıkardığı söylenebilir. Sosyal izolasyon durumu da bireylerin çeşitli psiko-sosyal sorunlar yaşamalarına ve internet kullanım sürelerinin artmasına neden olabilmektedir. Bireylerin internet kullanım sürelerinin artması ve psiko-sosyal sorunlar yaşamaları faktörleri de süreç içerisinde birbirlerini etkileyebilmektedir. Bu iki faktör beraberinde COVID-19 pandemisinde problemli internet kullanımı riskinin oluşmasına yol açabileceği söylenebilir. Bir sonraki bölümde COVID-19 pandemisi döneminde problemli internet kullanımına yönelik yapılan çeşitli araştırmalar ele alınacaktır.

\section{COVID-19 Pandemisinde Problemli İnternet Kullanımı İle İlgili Araştırmalar}

COVID-19 pandemisi ile birlikte bireylerin pandemi öncesine göre internette geçirdikleri sürenin artması, interneti sosyal medya kullanımı, çevrimiçi oyun oynama, alışveriş yapma ve film-dizi izleme gibi amaçlar için kullanma ve bu dönemde yaşanabilecek psiko-sosyal sorunlardan bir kaçış olarak interneti kullanmaları problemli internet kullanımı açısından risk oluşturabilmektedir. Bu başlıkta alanyazında COVID19 pandemisi döneminde problemli internet kullanımına ilişkin yapılan araștırmalara yer verilmiştir. 
Alanyazında yapılan araştırmalarda bireylerin pandemi öncesi ile karşılaştırıldığında pandemi döneminde internette geçirdikleri sürenin önemli oranda artış gösterdiği görülmüştür. Özdemir ve Arpacıŏglu (2020) tarafından Türkiye'de 1.020 yetişkin birey ile yapılan bir araştırmada, COVID-19 pandemisi döneminde sosyal medya kullanımının COVID-19 korkusu üzerinde etkisi incelenmiştir. Araştırma sonucunda, pandemi döneminde sosyal medyada daha fazla zaman geçiren bireylerin COVID-19 korkusu düzeylerinin daha yüksek olduğu görülmüștür. Ayrıca araștırmaya katılan bireylerin yaklaşık \%60’ sosyal medya kullanımlarının pandemi öncesine göre artış gösterdiğini ifade etmişlerdir. Araştırmaya katılan bireylerin yaklaşık \%35'i ise bu dönemde günlük ortalama 4 saatten fazla sosyal medyada zaman geçirdikleri görülmüştür. Islam ve arkadaşları (2020) tarafından Bangladeş'te 13.525 yetişkin ile yürütülen bir araştırmada, katılımcıların yaklaşık \%56'sı COVID-19 pandemisi döneminde günde ortalama 4 saatten daha fazla çevrimiçi zaman geçirdikleri görülmüştür. $\mathrm{Bu}$ dönemde katılımcıların \%64.9’u interneti sosyal medya kullanmak amacıyla kullanırken \%34.3'ü çevrimiçi oyun oynamak amacıyla, \%78'i ise dizi ve film gibi eğlenceli etkinlikleri için kullandıkları görülmüştür. İnterneti eğlence, oyun ve dizi-film içerikleri izlemek amacıyla kullanmanın problemli internet kullanımı açısından risk oluşturduğu göz önünde bulundurulduğunda (Filiz vd., 2014) bu oranların pandemi döneminde problemli internet kullanımı açısından endişe verici bir durum olduğu söylenebilir. Ayrıca araştırmada katılımcıların internet bağımlılık ölçeğinden aldığı puanların ortalaması 45 üzerinden 22.7 olarak bulunmuştur.

Duan ve arkadaşları (2020) tarafından Çin'de 3.613 birey ile yürütülen bir araştırmada ise katılımcların yaklaşık \%26'sı pandemi öncesinde internette günlük ortalama 3 saat ve üzeri vakit geçirirken pandemiyle birlikte katılımcıların yaklaşık \%57'si günlük ortalama 3 saat ve üzeri vakit geçirmeye başlamışlardır. Ayrıca pandemi döneminde katılımcıların yaklaşık \%23'ü akıllı telefon bağımlılığı belirtileri gösterirken \%6'sı internet bağımlılığı belirtileri göstermektedir. Bunlara ek olarak akıllı telefon bağımlılığı ve internet bağımlılığı belirtileri gösteren grubun göstermeyen gruba göre anlamlı olarak daha fazla kaygı yaşadıkları görülmüştür. Hashemi ve arkadaşları (2020) tarafından İran'da 651 birey ile yürütülen bir araştırmada ise katılımcıların yaklaşık \%32'si COVID-19 pandemisi döneminde günde ortalama en az 4 saat sosyal ağlarda vakit geçirdikleri görülmüştür. Ayrıca araştırmada, problemli internet kullanımı ile COVID-19 korkusu arasında .40 düzeyinde anlamlı bir ilişki bulunmuştur. Ayrıca yapılan yapısal eşitlik modellemesinde problemli internet kullanımının üstbilişsel inançlar, kaygı duyarlılı̆̆ı ve COVID-19 korkusu üzerinde dolaylı etkiler oluşturduğu görülmüştür. Problemli internet kullanımının bileşenlerinden birisi olan aşırı kullanım boyutu, bireylerin internette geçirdikleri sürenin artış göstermesi olarak ifade edilmektedir (Block, 2008). Bu kapsamda pandemi döneminde bireylerin internette geçirdikleri sürenin fazla olması problemli internet kullanımı açısından risk oluşturabileceği söylenebilir.

COVID-19 pandemisi döneminde problemli internet kullanımının yaygınlığını belirlemeye yönelik araștırmalarda elde edilen yaygınlık oranları da problemli internet kullanımı riskini görebilmek açısından önemli ipuçları verebilmektedir. Ayrıca araştırmalarda bireylerin problemli internet kullanım düzeyleri ile 
çeșitli psiko-sosyal özellikler arasındaki ilişkilerin incelenmesi, internet kullanımının pandeminin zorlu psikososyal deneyimlerinden bir kaçış olarak görülebileceğini gösterebilmektedir. Buna ek olarak pandeminin getirdiği psiko-sosyal etkileri, problemli internet kullanımının oluşturabileceği olumsuz etkiler daha da derinleştirebilmektedir. Sun ve arkadaşları (2020) tarafından Çin'de 6.416 birey ile yapılan bir araştırmada, katılımcıların \%46.8'inin COVID-19 pandemisi döneminde internet bağımlılık belirtilerinin artış gösterdiği ve \%16.6'sının pandemi sürecinde daha fazla internette kaldıkları görülmüştür. Dong ve arkadaşları (2020) tarafından Çin'de 2.050 çocuk ve ergenle yapılan bir araştırmada ise katılımcıların \%2.68'i internet bağımlılı̆g kriterlerini karşılarken \%33.37'si problemli internet kullanıcısı olarak sınıflandırılmıştır. Araştırmada, çocuk ve ergenlerde bu dönemde internet kullanımının pandemi öncesine göre büyük oranda artış gösterdiği görülmüştür. Ayrıca araştırmada, çocuk ve ergenlerin internet bağımlılık düzeyleri ile depresyon düzeyleri arasında $(\mathrm{r}=.257, \mathrm{p}<.001)$ ve stres düzeyleri arasında $(\mathrm{r}=.323, \mathrm{p}<.001)$ pozitif yönde anlamlı bir ilişki bulunmuştur. Yapılan regresyon analizinde ise COVID-19 pandemisi döneminde çocuk ve ergenlerin internet bağımlılık düzeylerinin \%29’unu stres ve depresyon düzeyleri açıkladığı görülmüştür.

Priego-Parra ve arkadaşları (2020) tarafından Meksika'da 561 birey ile yapılan bir araştırmada, araştırmaya katılan bireylerin \%62.7'sinin internet bağımlılığı riski taşıdığı görülmüştür. Ayrıca araştırmada, internet bağımlılık düzeyi yüksek olan bireylerin kaygı, depresyon ve uyku sorunları düzeylerinin daha yüksek olduğu görülmüștür. Bunlara ek olarak COVID-19 pandemisi döneminde bireylerin kaygı düzeylerinin \%19.6'sını internet bağımlılık düzeyinin açıkladığı görülmüştür. Siste ve arkadaşları (2020) tarafından Endonezya'da 4.734 yetişkin ile yapılan bir araștırmada ise COVID-19 pandemisi sürecinde internet bağımlılı̆̆ı yaygınlığı \%14.4 olarak bulunmuştur. Ayrıca katılımcıların pandemi öncesine göre internet kullanım oranları \%52 seviyesinde artış göstermiştir. Bunlara ek olarak katılımcıların yaklaşık \%4'ü aile içerisinde tanılanmış vakaların bulunduğunu ifade etmiştir. Bu katılımcıların yaklaşık \%23'ü ise internet bağımlılığı belirtileri taşıdığı görülmüştür. Araştırmada ayrıca ev içerisinde tanılanmış COVID-19 vakasına sahip olan, günlük internet kullanım süresi 11 saatten fazla olan, interneti sosyal medya ve çevrimiçi oyunlar için kullanan grupların internet bağımlılık riskleri diğer gruplara göre daha yüksek bulunmuştur. Ayrıca bireylerin internet bağımlılık düzeyleri ile SCL-90 belirti tarama envanterinin bütün alt boyutlarılya pozitif yönde .249 ile .320 arasında değişen pozitif yönde anlamlı ilişkiler bulunmuştur.

Lin (2020) tarafından Tayvan'da 1.060 ortaokul öğrencisi ile COVID-19 pandemisinin yoğun bir şekilde yaşandığı dönemde yürütülen kesitsel bir araştırmada, öğrenciler arasında internet bağımlılığının yaygınlığı \%24.4 olarak bulunmuştur. Ayrıca araştırma sonucunda, internet bağımlılı̆̆ı belirtileri gösteren grubun göstermeyen gruba göre nörotizm, dürtüsellik, depresyon, aleksitimi ve sanal sosyal destek düzeyleri daha yüksek bulunurken benlik saygısı, aile fonksiyonları, gerçek sosyal destek ve öznel iyi oluş düzeyleri daha düşük bulunmuştur. Bu sonuçlar; COVID-19 pandemisi döneminde ortaokul öğrencileri arasında internet bağımlılı̆̆ı belirtileri gösteren grubun psiko-sosyal özellikler açısından riskli durumda olduklarını göstermektedir. Prakash, Yadav ve Singh (2020) tarafından Hindistan'da 350 katılımcı ile yapılan bir 
araștırmada, katılımcıların yalnızca yaklaşık \%30'u normal internet kullanıcısı grubunda yer alırken diğerleri hafif, orta ve yüksek düzeyde internet bağımlılığı belirtileri gösteren grupta yer aldıkları görülmüştür. GómezGalán ve arkadaşları (2020) tarafından İspanya'da üniversite öğrencileri ile yapılan bir araştırmada, öğrencilerin yaklaşık \%22'si sosyal ağlara bağımlılık belirtileri göstermektedir. Ayrıca öğrencilerin \%9'u sosyal ağlara takıntı belirtileri gösterirken \%27.7'si sosyal ağların kullanımında öz kontrol eksikliği yaşadığı ve \%47.1'inin sosyal ağlarda aşırı vakit geçirdiği görülmüștür. Li ve arkadaşları (2020) tarafından 1.442 sağlık profesyoneli öğrencileri ile yapılan araştırmada ise katılımcıların internet bağımlılık düzeyleri yüksek psikolojik sıkıntı ve stres ile ilişkili bulunmuştur. Elhai ve arkadaşları (2020) tarafından Çin'de 908 katılımcı ile yapılan bir araştırmada, COVID-19 kaygısı ile problemli akıllı telefon kullanımı arasında pozitif yönde ilişki olduğu görülmüştür. Alheneidi ve arkadaşları (2021) tarafından Kuveyt ve Suudi Arabistan'da 593 katılımcı ile yürütülen bir araştırmada, COVID-19 pandemisi döneminde yalnızlığın problemli internet kullanımının anlamlı bir yordayıcısı olduğu görülmüştür. Panno ve arkadaşları (2020) tarafından İtalya'da 1.519 katılımcı ile yapılan bir araştırmada, COVID-19'un psikolojik etkileri sosyal medya bağımlılığı ile önemli oranda ilişkili olduğu görülmüştür. Ayrıca araştırmada katılımcıların \%20.5’i sosyal medya bağımlılığı belirtileri göstermektedir. Chen ve arkadaşları (2020) tarafından öğrencilerle yapılan bir araştırmada, COVID-19 pandemisinde problemli internet kullanımının psikolojik sıkıntılar ile ilişkili olduğu görülmüştür.

COVID-19 pandemisi döneminde internet kullanım amaçları da göz önünde bulundurulduğunda ise interneti sosyal medya kullanımı, çevrimiçi oyun oynama, alışveriş yapma ve video içerikleri takip etme amaçlı kullanım durumları problemli internet kullanımı açısından risk oluşturabilmektedir. Lemenager ve arkadaşları (2021) tarafından Almanya'da 3245 birey ile yapılan bir araştırmada, katılımcıların \%71.4'ü pandemi öncesine göre pandemide sosyal medyada geçirdikleri sürenin artış gösterdiğini ifade etmişlerdir. Bu dönemde erkek katılımcların oyun oynama ve erotik platformlarda zaman geçirme süreleri daha fazla artış gösterirken kadın katılımcıların sosyal paylaşım, bilgi arama ve video akışı platformlarında geçirdikleri sürenin daha fazla artış gösterdiği görülmüştür. Bu dönemde bu platformlarda geçen sürenin artması problemli internet kullanımı açısından risk oluşturabileceği söylenebilir. Fernandes ve arkadaşları (2020) tarafından Hindistan, Malezya, Meksika ve İngiltere'deki ergenler üzerinde yapılan bir araştırmada, problemli internet kullanımı ve sosyal medya kullanımı düzeyleri yüksek olan ergenlerin depresyon, yalnızlık, düşük uyku kalitesi ve pandemiye bağlı kaygı düzeyleri de yüksek bulunmuştur. Ayrıca araştırmada, pandemi öncesine göre pandemi döneminde sosyal medya kullanımı, çevrimiçi oyun oynama ve video içerikleri izleme sürelerinin önemli oranda artış gösterdiği görülmüştür. Kashif ve Aziz-Ur-Rehman (2020) tarafından 404 birey ile yapılan bir araştırmada, katılımcların \%67'sinin COVID-19 pandemisi döneminde boş zamanlarını sıklıkla sosyal medyada geçirdikleri görülmüştür. Ayrıca katılımcıların \%39’u bu dönemdeki sosyal medya kullanımlarının bağımlılık seviyesinde olabileceği konusunda endişe duyduklarını ifade etmişlerdir.

COVID-19 pandemisi döneminde bireylerin problemli internet kullanımlarına ilişkin araştırmaların daha çok nicel araştırma yöntemi deseni ile gerçekleştirildiği görülmüştür. Ülkemizde yapılan bir araştırmada 
ise nitel araştırma yöntemi kullanılarak bireylerin pandemi döneminde internet kullanım yaşantıları derinlemesine incelenmiștir. Baltacı, Akbulut ve Zafer (2020) tarafından Türkiye'de 52 üniversite öğrencisi ile yapılan bir nitel araştırmada, araştırmaya katılan üniversite öğrencilerinin COVID-19 döneminde internet kullanımına ilişkin yaşantıları incelenmiştir. Araştırmada, üniversite öğrencilerinin pandemi döneminde internet kullanımlarını kontrol etmekte zorluk yaşadıkları, kontrol edememekten dolayı olumsuz duygular yaşadıkları ve kendilerini bu durumdan dolayı internet bağımlısı olarak gördükleri ifade edilmiştir. Ayrıca üniversite öğrencilerinin pandemi döneminde internette vakit geçirmelerinden dolayı aile üyeleriyle daha az zaman geçirdikleri, aile üyeleriyle olan ilişkilerini zayıflattığı ve aile üyeleriyle etkileşimlerinden kaçınmak için internete yöneldikleri görülmüştür. Bunlara ek olarak üniversite öğrencilerinin pandemi dönemindeki internet kullanımlarının sosyal etkileşimlerini zayıflattığı, bu durumdan kaynaklı olumsuz duygular yaşadıkları ve fiziksel aktiviteler yapmalarını etkilediği görülmüştür. Araştırmaya katılan üniversite öğrencilerinin pandemi döneminde internet kullanımlarına ilişkin yaşantıları incelendiğinde, problemli internet kullanımı açısından riskli durumlar yaşadıkları görülmektedir.

\section{COVID-19 Pandemisinde Problemli İnternet Kullanımını Önlemeye İlişkin Öneriler}

COVID-19 pandemisinin bireyler üzerinde yarattığı psiko-sosyal etkiler ve bu döneminde sosyal izolasyon ile birlikte internette geçirilen sürenin artmasının beraberinde problemli internet kullanımı riskinin oluşmasına neden olabileceği alanyazında yapılan araştırmalarda desteklenmektedir. Bireylerin COVID-19 pandemisi döneminde birçok sorumluluğu yerine getirebilmek için bir firsat olarak görülebilen interneti yaşamlarına zarar vermeyecek ve kontrollü bir şekilde kullanabilmeleri ruh sağlığı durumları açısından büyük önem taşımaktadır. Ayrıca özellikle okulların uzaktan eğitime geçişi ile birlikte yaklaşık 1 yıldır öğrenciler eğitimlerini internet üzerinden sürdürmektedirler. Bu durum öğrencilerin internette geçirdikleri sürenin çok önemli oranda artış göstermesine neden olmuştur. Bu bağlamda özellikle pandeminin sona ermesiyle birlikte çocuklar, ergenler ve üniversite öğrencileri için problemli internet kullanımı riski yaşanması artış gösterebileceği düşünülmektedir. Bu bağlamda hem pandemi döneminde hem de pandemi sonrası dönemde bireylere yönelik yürütülecek bazı hizmetler problemli internet kullanımı riskinin yaygınlaşmasını engellemek adına önemli olabileceği söylenebilir. Bu kapsamda problemli internet kullanımı riskini önlemeye ilişkin şu önerilerde bulunulabilir (Ercan vd., 2020; Göker ve Turan, 2020; Király vd., 2020; Meng vd., 2020):

- Bütün yaş gruplarındaki bireylere yönelik problemli internet kullanımı konusunda farkındalık oluşturabilmek için çevrimiçi seminerler, etkinlikler veya atölyeler düzenlenebilir.

- Eğitimlerine uzaktan eğitim araçlarıyla devam eden öğrencilere yönelik internet kullanımlarını kontrol edebilmelerine ve problemli internet kullanımı riskinden kaçınabilmelerine yönelik kontrol becerilerinin kazandırılmasına yönelik psiko-eğitim programları düzenlenebilir.

- COVID-19 pandemisinin bireylerin psiko-sosyal sağlıkları üzerinde olumsuz etkiler oluşturması ve bu etkilerden kaçış olarak bireylerin internet kullanımına yönelmelerini önlemek adına 
pandemi döneminde koruyucu faktörlerin ele alınacağı önleyici psikolojik danışma ve rehberlik hizmetleri planlanabilir.

- Tedavi edilmemiş ruhsal durumların bu dönemde problemli internet kullanımı riskini arttırdığı göz önünde bulundurulduğunda kurum ve kuruluşlar tarafından bu bireylere yönelik ücretsiz psikolojik destek hizmetleri sunulabilir.

- Çocuk ve ergenlerin COVID-19 pandemi döneminde problemli internet kullanımı riskinden korunabilmeleri açısından ebeveynlere yönelik bilgi ve beceri kazandırıcı eğitimler düzenlenebilir. Çünkü bu süreçte ebeveynlerin çocuklarının teknoloji kullanımlarını sağlıklı bir şekilde kontrol edebilmeleri büyük önem taşımaktadır. Örneğin, bu dönemde ebeveynlerin çocuklarının zararlı içeriklerle karşılaşmalarını engellemek adına çeşitli kısıtlama uygulamaları kullanabilirler.

- Bu dönemde interneti problemli bir şekilde kullanan ebeveynlerin çocuklarında da problemli internet kullanım riski yaşanabileceği göz önünde bulundurularak ebeveynlere yönelik çevrimiçi eğitimler gerçekleștirilebilir.

- Bireylerin bu dönemde problemli internet kullanım risklerini belirlemeye yönelik ölçme ve değerlendirme yapılarak riskli gruptaki bireylere yönelik grupla psikolojik danışma hizmetleri planlanabilir.

- Bu dönemde çocuk ve ergenlerin zorunlu çevrimiçi kullanım dışında daha çok aile üyeleriyle ve akranlarıla sosyal mesafe ve hijyen kurallarına dikkat ederek etkileşim kurmaları desteklenebilir. Özellikle aile içerisinde iletişimi güçlendirecek aktivitelerin gerçekleştirilmesi bireylerin bu dönemde yaşayabilecekleri problemli internet kullanım riskinin önlenebilmesi açısından önemli olabileceği düşünülmektedir.

- $\mathrm{Bu}$ dönemde bireylerin psikolojik sağlıklarının korunması ve sosyal destek ağlarının güçlendirilmesine yönelik hizmetler yürütülebilir.

- $\mathrm{Bu}$ dönemde bireylerin sosyal mesafe ve maske kurallarına uyarak fiziksel aktiviteler gerçekleştirmeleri bireylerin ruh sağlıklarının korunması ve problemli internet kullanımı riski açısından koruyucu olduğu düşünülmektedir.

- Bu dönemde COVID-19 ile ilgili haberleri ve gelişmeleri Dünya Sağlık Örgütü ve Sağlık Bakanlığı gibi güvenilir içeriklerden takip etmek ruh sağlığının korunması ve problemli internet kullanımı riskinin önlenmesi açısından önemli olabileceği söylenebilir.

- $\mathrm{Bu}$ dönemde yaşanan yoğun psikolojik durumlar karşısında başa çlkılamayan durumlarda psikiyatrist, psikolojik danışman ve psikolog gibi ruh sağlığı uzmanlarından psikolojik destek alınabilir. 


\section{SONUÇ}

$\mathrm{Bu}$ araştırmada, COVID-19 pandemisi döneminde bireylerin daha uzun süre evde kalmalarıyla birlikte internette geçirilen sürenin artması sonucunda oluşan problemli internet kullanım riski alanyazın ışığında incelenmiștir. Araştırmada ilk olarak COVID-19 pandemisinin oluşturduğu psiko-sosyal etkiler çeşitli ülkelerde yapılan araştırmalar ışığında ele alınmıştır. Yapılan bu araştırmalar genel olarak incelendiğinde, COVID-19 pandemisinin fiziksel yansımalarının yanı sıra psikolojik ve sosyal yansımalarının da ciddi olduğunu göstermektedir. Araştırmada daha sonra problemli internet kullanımını açıklayan kuramlar ve modeller ışığında COVID-19 pandemisi döneminde problemli internet kullanım riski açıklanmıștır. Bu kuram ve modeller ışığında; COVID-19 pandemisinin sosyal izolasyonu beraberinde getirdiği ve sosyal izolasyonla birlikte bireylerin psiko-sosyal sorunlar yaşadıkları ve internette geçirdikleri sürenin arttığı görülmektedir. Bireylerin bu dönemde yaşadıkları psiko-sosyal sorunlar ile internette geçirilen sürenin artması birbirlerini etkilemekle birlikte problemli internet kullanımı riskinin oluşmasına da yol açabileceği söylenebilir. Sonrasında araştırmada, COVID-19 pandemisi döneminde problemli internet kullanımı riskiyle ilişkili yapılan araştırmalar ele alınmıştır. Alanyazında bu konu ile ilgili yapılan araştırmalar genel olarak özetlendiğinde; COVID-19 pandemisiyle birlikte bireylerin problemli internet kullanım oranlarında önemli artışlar göründügü ve bu durumun bireylerin psiko-sosyal sağlıkları açısından olumsuz etkiler oluşturduğu görülmüştür. Son olarak ise COVID-19 döneminde çocukların, ergenlerin ve yetişkinlerin problemli internet kullanımı riskinden korunabilmelerine yönelik kurum ve kuruluşlara, ruh sağlığı uzmanlarına, bireylere ve ebeveynlere çeşitli önerilerde bulunulmuştur. 


\section{KAYNAKÇA}

Al Zubayer, A., Rahman, M. E., Islam, M. B., Babu, S. Z. D., Rahman, Q. M., Bhuiyan, M. R. A. M., ... Habib, R. B. (2020). Psychological states of Bangladeshi people four months after the COVID-19 pandemic: An online survey. Heliyon, 6(9), e05057. https://doi.org/10.1016/j.heliyon.2020.e05057

Alheneidi, H., AlSumait, L., AlSumait, D. ve Smith, A. P. (2021). Loneliness and problematic internet use during $\begin{array}{lllll}\text { COVID-19 lock-down. } & \text { Behavioral } & \text { Sciences, } & 11(1), & 5 .\end{array}$ https://doi.org/https://doi.org/10.3390/bs11010005

Ardebili, M. E., Naserbakht, M., Bernstein, C., Alazmani-Noodeh, F., Hakimi, H. ve Ranjbar, H. (2020). Healthcare providers experience of working during the COVID-19 pandemic: A qualitative study. American Journal of Infection Control, InPress. https://doi.org/10.1016/j.ajic.2020.10.001

Avşaroğlu, S. ve Akbulut, Ö. F. (2020). Sağlıklı aile yapısı açısından bir risk faktörü: İnternet bağımlılığı. International Social Sciences Studies Journal, 6(65), 2879-2902. http://dx.doi.org/10.26449/sssj.2456

Babore, A., Lombardi, L., Viceconti, M. L., Pignataro, S., Marino, V., Crudele, M., ... Trumello, C. (2020). Psychological effects of the COVID-2019 pandemic: Perceived stress and coping strategies among $\begin{array}{lllll}\text { healthcare } & \text { professionals. } & \text { Psychiatry } & \text { Research, } & \text { 293, }\end{array}$ https://doi.org/10.1016/j.psychres.2020.113366

Balcı, E., Durmuş, H. ve Sezer, L. (2021). Corona günlerinde uzaktan eğitim bağımllık gelişiminde bir risk oluşturur mu?. Bağımlılık Dergisi, 22(1), 100-102.

Baltacı, Ö., Akbulut, Ö. F. ve Zafer, R. (2020). COVID-19 pandemisinde problemli internet kullanımı: Bir nitel araştırma. Kırșehir Ahi Evran Üniversitesi Sağlık Bilimleri Enstitüsü Dergisi, 1(3), 126-140.

Bayrak Ayas, E. (2020). Investigation of digital game addiction levels of high school students. International Online Journal of Educational Sciences, 12(3), 81-91. https://doi.org/10.15345/iojes.2020.03.007

BBC Türkçe. (2020). Koronavirüs: Adım adım Türkiye'nin Covid-19'la mücadelesi. 31.01 .2021 tarihinde https://www.bbc.com/turkce/haberler-turkiye-52899914 adresinden alındı.

Benke, C., Autenrieth, L. K., Asselmann, E. ve Pané-Farré, C. A. (2020). Lockdown, quarantine measures, and social distancing: Associations with depression, anxiety and distress at the beginning of the COVID-19 pandemic among adults from Germany. Psychiatry Research, 293, 113462. https://doi.org/10.1016/j.psychres.2020.113462

Block, J. J. (2008). Issues for DSM-V: Internet addiction. The American Journal of Psychiatry, 165, 306-307. https://doi.org/10.1176/appi.ajp.2007.07101556

Budak, C. (2016). Ortaokul öğrencilerinde internet bağımlılı̆̆ı, obezite prevelansı ve fiziksel aktivite katılım düzeylerinin incelenmesi. [Yayımlanmamış yüksek lisans tezi]. Muğla Sıtkı Koçman Üniversitesi. 
Budak, E., Taymur, İ., Askin, R., Gungor, B. B., Demirci, H., Akgül, A. İ. ve Anil Sahin, Z. (2015). Relationship between internet addiction, psychopathology and self-esteem among university students. The European Research Journal, 1(3), 128-135. https://doi.org/10.18621/eurj.2015.1.3.128

Bulut, S. ve Suluk, I. (2020). Coronavirus outbreak in Turkey and its possible psychological effects. Open Access Journal of Behavioural Science \& Psychology, 3(2), 1-3.

Buzkıran, B. (2017). 8. sınıf öğrencilerinin sosyal bilgiler dersi başarı düzeylerinin problemli internet kullanımı ve bazı değişkenler açısından incelenmesi. TRT Akademi, 2(4), 413-439.

Caplan, S. E. (2010). Theory and measurement of generalized problematic Internet use: A two-step approach. Computers in Human Behavior, 26(5), 1089-1097. https://doi.org/10.1016/j.chb.2010.03.012

Cerniglia, L., Zoratto, F., Cimino, S., Laviola, G., Ammaniti, M. ve Adriani, W. (2017). Internet addiction in adolescence: Neurobiological, psychosocial and clinical issues. Neuroscience \& Biobehavioral Reviews, 76, 174-184. https://doi.org/10.1016/j.neubiorev.2016.12.024

Chen, C. Y., Chen, I. H., O’Brien, K., Latner, J. D. ve Lin, C. Y. (2020). Psychological distress and internet-related behaviors between schoolchildren with and without overweight during the COVID-19 outbreak. Research Square, 1-20. https://doi.org/https://doi.org/10.21203/rs.3.rs-27322/v1

Chen, R. N., Liang, S. W., Peng, Y., Li, X. G., Chen, J. B., Tang, S. Y. ve Zhao, J. B. (2020). Mental health status and change in living rhythms among college students in China during the COVID-19 pandemic: A large-scale $\begin{array}{llllll}\text { survey. Journal of } & \text { Psychosomatic }\end{array}$ https://doi.org/10.1016/j.jpsychores.2020.110219

Chi, X., Hong, X. ve Chen, X. (2020). Profiles and sociodemographic correlates of internet addiction in early adolescents in Southern China. Addictive Behaviors, 106, 1-7. https://doi.org/10.1016/j.addbeh.2020.106385

Çırak, Z. D., Yetiş, G. ve Gürbüz, P. (2018). Üniversite öğrencilerinin internet kullanımlarının aile ilişkileri ve sorumlulukları yerine getirmelerindeki etkisi. İnönü Üniversitesi Sağlık Hizmetleri Meslek Yüksek Okulu Dergisi, 6(2), 1-8.

Daks, J. S., Peltz, J. S. ve Rogge, R. D. (2020). Psychological flexibility and inflexibility as sources of resiliency and risk during a pandemic: Modeling the cascade of COVID-19 stress on family systems with a contextual behavioral science lens. Journal of Contextual Behavioral Science, 18, 16-27. https://doi.org/10.1016/j.jcbs.2020.08.003

Davis, R. A. (2001). A cognitive-behavioral model of pathological Internet use. Computers in Human Behavior, 17, 187-195. https://doi.org/10.1016/S0747-5632(00)00041-8 
Dong, H., Yang, F., Lu, X. ve Hao, W. (2020). IInternet addiction and related psychological factors among children and adolescents in China during the coronavirus disease 2019 (COVID-19) epidemic. Frontiers in Psychiatry, 11, 751. https://doi.org/10.3389/fpsyt.2020.00751

Duan, L., Shao, X., Wang, Y., Huang, Y., Miao, J., Yang, X. ve Zhu, G. (2020). An investigation of mental health status of children and adolescents in china during the outbreak of COVID-19. Journal of Affective Disorders, 275, 112-118. https://doi.org/10.1016/j.jad.2020.06.029

Dürmüş, G. (2018). Adölesanlarda obezite ve problemli internet kullanımı ilişkisinin belirlenmesi. [Yayımlanmamıș yüksek lisans tezi]. Hasan Kalyoncu Üniversitesi.

Eidi, A. ve Delam, H. (2020). Internet addiction is likely to increase in home quarantine caused by coronavirus disease 2019 (COVID 19). Journal of Health Sciences \& Surveillance System, 8(3), 142-143. https://doi.org/10.30476/jhsss.2020.87015.1104

El Keshky, M. E. S., Alsabban, A. M. ve Basyouni, S. S. (2020). The psychological and social impacts on personal stress for residents quarantined for COVID-19 in Saudi Arabia. Archives of Psychiatric Nursing, In Press. https://doi.org/10.1016/j.apnu.2020.09.008

Elhai, J. D., Yang, H., McKay, D. ve Asmundson, G. J. (2020). COVID-19 anxiety symptoms associated with problematic smartphone use severity in Chinese adults. Journal of Affective Disorders, 274, 576-582. https://doi.org/10.1016/j.jad.2020.05.080

Ercan, E. S., Rodopman Arman, A., İnal Emiroğlu, N., Behice Öztop, D. ve Yalçın, Ö. (2020). Covid-19 (korona) virüs salgını sırasında aile, çocuk ve ergenlere yönelik psikososyal ve ruhsal destek rehberi. 31.01.2021 tarihinde https://www.ankara.edu.tr/wp-content/uploads/sites/6/2020/03/cogepdercovid19rehberi30mart2020.pdf.pdf adresinden alındı.

Fernandes, B., Biswas, U. N., Mansukhani, R. T., Casarín, A. V. ve Essau, C. A. (2020). The impact of COVID-19 lockdown on internet use and escapism in adolescents. Revista de Psicología Clínica Con Niños y Adolescentes, 7(3), 59-65.

Filiz, O., Osman, E., Dönmez, F. İ. ve Kurt, A. A. (2014). BÖTE bölümü öğrencilerinin sosyal ağ siteleri kullanım amaçları ile internet bağımlılıkları arasındaki ilişkinin incelenmesi. Journal of Instructional Technologies \& Teacher Education, 3(2), 26-28.

Fitzpatrick, K. M., Drawve, G. ve Harris, C. (2020). Facing new fears during the COVID-19 pandemic: The State of America's mental health. Journal of Anxiety Disorders, 75, 102291. https://doi.org/10.1016/j.janxdis.2020.102291

Gao, J., Zheng, P., Jia, Y., Chen, H., Mao, Y., Chen, S., ... Dai, J. (2020). Mental health problems and social media exposure during COVID-19 outbreak. PloS One, 15(4), e0231924. https://doi.org/10.1371/journal.pone.0231924 
Geng, J., Han, L., Gao, F., Jou, M. ve Huang, C.-C. (2018). Internet addiction and procrastination among Chinese young adults: A moderated mediation model. Computers in Human Behavior, 84, 320-333. https://doi.org/https://doi.org/10.1016/j.chb.2018.03.013

Göker, M. E. ve Turan, Ș. (2020). COVID-19 pandemisi sürecinde problemli teknoloji kullanımı. ESTÜDAM Halk Sağlı̆̆ı Dergisi, 5, 108-114. https://doi.org/https://doi.org/10.35232/estudamhsd.767526

Gómez-Galán, J., Martínez-López, J. Á., Lázaro-Pérez, C. ve Sarasola Sánchez-Serrano, J. L. (2020). Social networks consumption and addiction in college students during the COVID-19 pandemic: Educational approach to responsible use. Sustainability, 12(18), 7737. https://doi.org/10.3390/su12187737

Griffith, E. (2020). COVID-19 Leads to Upsurge in Kids' Streaming Screen-Time. 31.01.2021 tarihinde https://www.pcmag.com/news/covid-19-leads-to-upsurge-in-kids-streaming-screen-time adresinden alındı.

Guessoum, S. B., Lachal, J., Radjack, R., Carretier, E., Minassian, S., Benoit, L. ve Moro, M. R. (2020). Adolescent psychiatric disorders during the COVID-19 pandemic and lockdown. Psychiatry Research, 291, 113264. https://doi.org/10.1016/j.psychres.2020.113264

Güleryüz, S., Esentaş, M., Yıldız, K. ve Güzel, P. (2020). Sosyal izolasyon sürecindeki bireylerin serbest zaman değerlendirme biçimleri: Sosyal medya kullanım amaçları ile sosyal medya bağımlılığı ilişkisinin incelenmesi. Focuss Spor Yönetimi Araştırmaları Dergisi, 1(1), 31-45.

Guo, J., Fu, M., Liu, D., Zhang, B., Wang, X. ve van IJzendoorn, M. H. (2020). Is the psychological impact of exposure to COVID-19 stronger in adolescents with pre-pandemic maltreatment experiences? A survey of rural Chinese adolescents. Child Abuse Neglect, 110, 104667. https://doi.org/10.1016/j.chiabu.2020.104667

Hashemi, S. G. S., Hosseinnezhad, S., Dini, S., Griffiths, M. D., Lin, C. Y. ve Pakpour, A. H. (2020). The mediating effect of the cyberchondria and anxiety sensitivity in the association between problematic internet use, metacognition beliefs, and fear of COVID-19 among Iranian online population. Heliyon, 6(10), e05135. https://doi.org/https://doi.org/10.1016/j.heliyon.2020.e05135

Islam, M. S., Sujan, M. S. H., Tasnim, R., Ferdous, M. Z., Masud, J. H. B., Kundu, S., ... Griffiths, M. D. (2020). Problematic internet use among young and adult population in Bangladesh: Correlates with lifestyle and online activities during the COVID-19 pandemic. Addictive Behaviors Reports, 12, 100311. https://doi.org/10.1016/j.abrep.2020.100311

Jiang, R. (2020). Knowledge, attitudes and mental health of university students during the COVID-19 pandemic in China. Children and Youth Services Review, 119, 105494. https://dx.doi.org/10.1016\%2Fj.childyouth.2020.105494 
Kandell, J. J. (1998). Internet addiction on campus: The vulnerability of college students. Cyberpsychology and Behavior, 1(1), 11-17. https://doi.org/10.1089/cpb.1998.1.11

Kashif, M. ve Aziz-Ur-Rehman, M. K. J. (2020). Social media addiction due to coronavirus. International Journal of Medical Science in Clinical Research and Review, 3(4), 331-336.

King, D. L., Delfabbro, P. H., Billieux, J. ve Potenza, M. N. (2020). Problematic online gaming and the COVID-19 pandemic. Journal of Behavioral Addictions, 9(2), 184-186. https://doi.org/10.1556/2006.2020.00016

Király, O., Potenza, M. N., Stein, D. J., King, D. L., Hodgins, D. C., Saunders, J. B. ve Abbott, M. W. (2020). Preventing problematic internet use during the COVID-19 pandemic: Consensus guidance. Comprehensive Psychiatry, 100, 1-4. https://doi.org/10.1016/j.comppsych.2020.152180

LaRose, R., Lin, C. A. ve Eastin, M. S. (2003). Unregulated Internet usage: Addiction, habit, or deficient selfregulation?. Media Psychology, 5(3), 225-253. https://doi.org/10.1207/S1532785XMEP0503_01

Lebel, C., MacKinnon, A., Bagshawe, M., Tomfohr-Madsen, L. ve Giesbrecht, G. (2020). Elevated depression and anxiety among pregnant individuals during the COVID-19 pandemic. Journal of Affective Disorders, 277, 5-13. https://doi.org/10.1016/j.jad.2020.07.126

Lemenager, T., Neissner, M., Koopmann, A., Reinhard, I., Georgiadou, E., Müller, A., Kiefer, F. ve Hillemacher, T. (2021). COVID-19 lockdown restrictions and online media consumption in Germany. International Journal of Environmental Research and Public Health, 18(1), 14. https://doi.org/10.3390/ijerph18010014

Li, G., Hou, G., Yang, D., Jian, H. ve Wang, W. (2019). Relationship between anxiety, depression, sex, obesity, and internet addiction in Chinese adolescents: A short-term longitudinal study. Addictive Behaviors, 90, 421427. https://doi.org/10.1016/j.addbeh.2018.12.009

Li, Y., Wang, Y., Jiang, J., Valdimarsdóttir, U., Fall, K., Fang, F., .. . ve Zhang, W. (2020). Psychological distress among health professional students during the COVID-19 outbreak. Psychological Medicine, 1-3. https://doi.org/10.1017/S0033291720001555

Lin, M. P. (2020). Prevalence of internet addiction during the covid-19 outbreak and its risk factors among junior high school students in Taiwan. International Journal of Environmental Research and Public Health, 17(22), 8547. https://doi.org/10.3390/ijerph17228547

Lin, Y. J., Hsiao, R. C., Liu, T. L. ve Yen, C. F. (2019). Bidirectional relationships of psychiatric symptoms with internet addiction in college students: A prospective study. Journal of the Formosan Medical Association, 1-8. https://doi.org/10.1016/j.jfma.2019.10.006

Liu, C. H., Stevens, C., Conrad, R. C. ve Hahm, H. C. (2020). Evidence for elevated psychiatric distress, poor sleep, and quality of life concerns during the COVID-19 pandemic among US young adults with suspected and 
Problemli Internet Kullanımında Güncel Bir Risk Faktörü: COVID-19 Pandemisi

Önder Baltacl, Ömer Faruk Akbulut, Ebru Yılmaz

$\begin{array}{llllll}\text { reported psychiatric } & \text { diagnoses. Psychiatry } & \text { Research, } & 292, & \end{array}$ https://doi.org/10.1016/j.psychres.2020.113345

Liu, C. Y. ve Kuo, F. Y. (2007). A study of internet addiction through the lens of the interpersonal theory. CyberPsychology \& Behavior, 10(6), 799-804. https://doi.org/10.1089/cpb.2007.9951

MacIntyre, P. D., Gregersen, T. ve Mercer, S. (2020). Language teachers' coping strategies during the Covid-19 conversion to online teaching: Correlations with stress, wellbeing and negative emotions. System, 94, 102352. https://doi.org/10.1016/j.system.2020.102352

Malesza, M. ve Kaczmarek, M. C. (2020). Predictors of anxiety during the COVID-19 pandemic in Poland. Personality and Individual Differences, 170, 110419. https://doi.org/10.1016/j.paid.2020.110419

Meng, S., Dong, P., Sun, Y., Li, Y., Chang, X., Sun, G., Zheng, X., Sun, Y., Sun, Y., Yuan, K., Sun, H., Wang, Y., Zhao, M., Tao, R., Domingo, C., Bao, Y., Kosten, T., Lu, L. ve Shi, J. (2020). Guidelines for prevention and treatment of internet addiction in adolescents during home quarantine for the COVID-19 pandemic. Heart and Mind, 4(4), 95-99. https://doi.org/10.4103/hm.hm_36_20

Mota, J., Ribeiro, J., Santos, M. P. ve Gomes, H. (2006). Obesity, physical activity, computer use, and TV viewing in

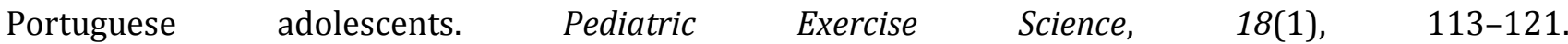
https://doi.org/10.1123/pes.18.1.113

Özcan, A., Özdil, K. ve Küçük Öztürk, G. (2020). Examination of some psychological variables that predict internet addiction in university students: A university in cappadocia. Journal of International Health Sciences and Management, 6(10), 74-89.

Özdemir, D. ve Arpacıoğlu, S. (2020). Sosyal Medya Kullanımı, Sağlık Algısı ve Sağlık Arama Davranışının Koronavirüs Korkusu Üzerine Etkisi. Psikiyatride Güncel Yaklaşımlar, 12(1), 1-15. https://doi.org/10.18863/pgy.803145

Panno, A., Carbone, G. A., Massullo, C., Farina, B. ve Imperatori, C. (2020). CoVID-19 related distress is associated with alcohol problems, social media and food addiction symptoms: Insights from the Italian experience during the cockdown. Frontiers in Psychiatry, 11, 1314. https://doi.org/10.3389/fpsyt.2020.577135

Peng, W., Li, D., Li, D., Jia, J., Wang, Y. ve Sun, W. (2019). School disconnectedness and Adolescent Internet Addiction: Mediation by self-esteem and moderation by emotional intelligence. Computers in Human Behavior, 98, 111-121. https://doi.org/10.1016/j.chb.2019.04.011

Pierce, M., Hope, H., Ford, T., Hatch, S., Hotopf, M., John, A., ... Abel, K. M. (2020). Mental health before and during the COVID-19 pandemic: a longitudinal probability sample survey of the UK population. The Lancet Psychiatry, 7(10), 883-892. https://doi.org/10.1016/S2215-0366(20)30308-4 
Planchuelo-Gómez, Á., Odriozola-González, P., Irurtia, M. J. ve de Luis-García, R. (2020). Longitudinal evaluation of the psychological impact of the COVID-19 crisis in Spain. Journal of Affective Disorders, 277, 842-849. https://doi.org/10.1016/j.jad.2020.09.018

Prakash, S., Yadav, J. S. ve Singh, T. B. (2020). An online cross-sectional study to assess the prevalence of internet addiction among people staying at their home during lockdown due to COVID-19. Int J Indian Psychol, 8(3), 424-432. https://doi.org/ 10.25215/0803.052

Priego-Parra, B. A., Triana-Romero, A., Pinto-Gálvez, S. M., Ramos, C. D., Salas-Nolasco, O., Reyes, M. M., Ramosde-la-Medina, A. ve Remes-Troche, J. M. (2020). Anxiety, depression, attitudes, and internet addiction during the initial phase of the 2019 coronavirus disease (COVID-19) epidemic: A cross-sectional study in México. MedRxiv, 2020.05.10.20095844. https://doi.org/10.1101/2020.05.10.20095844

Ruiz-Frutos, C., Ortega-Moreno, M., Allande-Cussó, R., Domínguez-Salas, S., Dias, A. ve Gómez-Salgado, J. (2020). Health-related factors of psychological distress during the COVID-19 pandemic among non-health workers in Spain. Safety Science, 133, 104996. https://doi.org/10.1016/j.ssci.2020.104996

Siste, K., Hanafi, E., Lee Thung Sen, H. C., Adrian, L. P. S., Limawan, A. P., Murtani, B. J. ve Suwartono, C. (2020). The impact of physical distancing and associated factors towards internet addiction among adults in Indonesia during COVID-19 pandemic: A nationwide web-based study. Frontiers in Psychiatry, 11, 580977. https://doi.org/10.3389/fpsyt.2020.580977

Statista. (2021). Coronavirus: impact on online usage in the U.S. - Statistics \& Facts. 31.01 .2021 tarihinde https://www.statista.com/topics/6241/coronavirus-impact-on-online-usage-in-the-us/ adresinden alındi.

Suler, J. R. (1999). To get what you need: Healthy and pathological internet use. CyberPsychology \& Behavior, 2(5), 385-393. https://doi.org/10.1089/cpb.1999.2.385

Sun, Y., Li, Y., Bao, Y., Meng, S., Sun, Y., Schumann, G., ... Shi, J. (2020). Brief report: increased addictive internet and substance use behavior during the COVID-19 pandemic in China. The American Journal on Addictions, 29(4), 268-270. https://doi.org/10.1111/ajad.13066

Tam, P. ve Walter, G. (2013). Problematic internet use in childhood and youth: evolution of a 21st century affliction. Australasian Psychiatry, 21(6), 533-536. https://doi.org/10.1177\%2F1039856213509911

Tan, B. Y., Abhiram, K., Lim, L. J., Tan, M., Chua, Y. X., Tan, L., ... Kinross, J. (2020). Burnout and associated factors amongst healthcare workers in Singapore during the COVID-19 pandemic. Journal of the American Medical Directors Association, 21, 1751-1758. https://doi.org/10.1016/j.jamda.2020.09.035

Tao, Z. L. ve Liu, Y. (2009). Is there a relationship between Internet dependence and eating disorders? A comparison study of Internet dependents and non-Internet dependents. Eating and Weight DisordersStudies on Anorexia, Bulimia and Obesity, 14(2-3), e77-e83. 
T.C. Sağlık Bakanlığı (2020). COVID-19 bilgilendirme sayfası. 06.02.2021 tarihinde https://covid19.saglik.gov.tr/ adresinden alındl.

Tso, I. F. ve Park, S. (2020). Alarming levels of psychiatric symptoms and the role of loneliness during the COVID-19 epidemic: A case study of Hong Kong. Psychiatry Research, 293, 113423. https://doi.org/10.1016/j.psychres.2020.113423

Wang, J., Wang, Z., Liu, X., Yang, X., Zheng, M. ve Bai, X. (2020). The impacts of a COVID-19 epidemic focus and general belief in a just world on individual emotions. Personality and Individual Differences, 168, 110349. https://doi.org/10.1016/j.paid.2020.110349

Wąsiński, A. ve Tomczyk, Ł. (2015). Factors reducing the risk of internet addiction in young people in their home environment. Children and Youth Services Review, 57, 68-74. https://doi.org/10.1016/j.childyouth.2015.07.022

World Health Organization (2020). WHO coronavirus disease (COVID-19) dashboard. 06.02.2021 tarihinde https://covid19.who.int/ adresinden alındı.

Xin, M., Xing, J., Pengfei, W., Houru, L., Mengcheng, W. ve Hong, Z. (2018). Online activities, prevalence of Internet addiction and risk factors related to family and school among adolescents in China. Addictive Behaviors Reports, 7, 14-18. https://doi.org/10.1016/j.abrep.2017.10.003

Yıldırım, M. S. (2016). Ergenlerde internet bağımlılı̆ıııı obezite ve benlik saygısı ile ilişkisinin incelenmesi. [Yayımlanmamış yüksek lisans tezi]. İstanbul Gelişim Üniversitesi, Sosyal Bilimler Enstitüsü, İstanbul.

Young, K. S. ve De Abreu, C. (2011). Internet addiction: A handbook and guide to evaluation. John Wiley \& Sons, Inc. 


\section{EXTENDED ABSTRACT}

\section{Introduction.}

COVID-19 disease caused by SAR-CoV-2, which started in China towards the end of 2019 and spread rapidly to the whole world, has become a global problem by showing a great spread in 2020 and it has become a pandemic by the World Health Organization (TC Ministry of Health, 2020; WHO, 2020). The rapid spread of the COVID-19 pandemic and its lethal effects has caused many countries to apply different restrictions in education, professional and social life. In our country in this context; It is known that different measures are taken, such as the imposition of curfew restrictions for various age groups, the continuation of the activities of education levels from pre-school to higher education through distance education, the imposition of curfews on weekends and travel restrictions (BBC Turkish, 2020; Turkish Ministry of Health, 2020). In addition, it is known that individuals isolate themselves in order not to get this disease and there is a decrease in their interactions in social life (Ruiz-Frutos et al., 2020). In addition, it has been observed that individuals are constantly exposed to news about the COVID-19 pandemic in the media during this period, causing them to experience intense stress and anxiety (Al Zubayer et al., 2020; Gao et al., 2020; Planchuelo-Gómez et al., 2020; Wang et al., 2020). Although these decreases in the interactions of individuals in their social lives compared to before the COVID-19 pandemic and the increase in the time spent at home have a protective role in terms of physical health, they may pose a risk in terms of experiencing various problems in terms of psycho-social health (Benke et al., 2020). In a study conducted on the internet usage rates during the COVID-19 pandemic process in the United States, it was observed that the internet usage rates of individuals increased compared to before the pandemic. A similar result was encountered in a study conducted in Sweden (Statista, 2021). In addition, another study showed that during the COVID-19 pandemic, the time spent by children in front of the screen increased significantly (Griffith, 2020). The time individuals spend in online games during the pandemic period has also increased significantly compared to before the pandemic (King et al., 2020). Increasing online time with the COVID-19 pandemic can pose a risk in terms of problematic internet use. In this study, the problematic internet use situation, which can be perceived as a problem in terms of psycho-social lives, was discussed with the increase of time spent on the internet by individuals staying at home.

\section{Psycho-social Effects of the COVID-19 Pandemic.}

After the COVID-19 pandemic emerged, the physical health of individuals was focused first and various measures were taken to protect the physical health of individuals. Within the framework of these regulations, regulations for protecting individuals' psycho-social health have been neglected. In the studies conducted in the literature, it has been observed that the COVID-19 pandemic causes significant psycho-social problems in all individuals from children to the elderly (Bulut \& Suluk, 2020; Malesza \& Kaczmarek, 2020).

\section{Problematic Internet Use in the COVID-19 Pandemic.}


It can be said that the COVID-19 pandemic has brought about social isolation. Social isolation can also cause individuals to experience various psycho-social problems and increase the duration of internet use. The factors that individuals' increase in Internet usage time and experience psycho-social problems can also affect each other in the process. It can be said that these two factors can lead to the risk of problematic internet use in the COVID-19 pandemic. When the researches on this subject are summarized in the literature; It has been observed that with the COVID-19 pandemic, individuals have seen significant increases in problematic internet use rates, and this situation has negative effects on the psycho-social health of individuals.

\section{Suggestions.}

It is supported by researches in the literature that the psycho-social effects of the COVID-19 pandemic on individuals and the increase in time spent on the internet along with social isolation in this period may cause the risk of problematic internet use. The ability of individuals to use the Internet, which can be seen as an opportunity to fulfill many responsibilities during the COVID-19 pandemic, without harming their lives and in a controlled manner is of great importance in terms of mental health conditions. In addition, with the transition of schools to distance education, students have been continuing their education over the internet for about 1 year. This situation has caused a significant increase in the time spent by students on the internet. In this context, it is thought that the risk of problematic internet use may increase for children, adolescents and university students, especially with the end of the pandemic. In this context, it can be said that some services to be carried out for individuals in both the pandemic period and the post-pandemic period may be important to prevent the spread of problematic internet use risk. 